\title{
HTLV-3 and HTLV-4 antisense proteins activate JunB-, C-Jun- and JunD-dependent transcription
}

\author{
Émilie Larocque ${ }^{1,2^{*}}$, Guy Lemay ${ }^{2}$, Jean-Michel Mesnard ${ }^{3}$, William M Switzer ${ }^{4}$, Benoit Barbeau ${ }^{1}$ \\ From 15th International Conference on Human Retroviruses: HTLV and Related Viruses \\ Leuven and Gembloux, Belgium. 5-8 June 2011
}

\section{Background}

The antisense transcript-encoded HBZ protein acts upon viral and cellular gene expression through its modulation of the activation of transcription factors such as Jun family members. A possible link between HBZ and ATL development has also been highlighted. HTLV-3 and HTLV-4 are two newly discovered human retroviruses closely related to HTLV-1; no known diseases have yet been associated to these viruses. Based on previous in silico analyses, our aim was to test for the presence of antisense transcripts in these new viruses and to functionally assess these viral proteins.

\section{Results}

By RT-PCR analyses, HTLV-3 and HTLV-4 were shown to produce spliced antisense transcripts termed APH (Antisense Protein of HTLV)-3 and APH-4. Confocal microscopy analyses of cells expressing Myc- or GFP-tagged APH-3 and APH-4 showed distinct localization but partial colocalization with $\mathrm{HBZ}$ to the nucleus and the nucleoli. Using LTR-luciferase constructs, we demonstrated that $\mathrm{APH}-3$ and $\mathrm{APH}-4$ inhibited Tax 1 and Tax 3 transactivation of respective LTRs. In transfection experiments with a collagenase promoter-driven luciferase reporter construct, we showed that APH-3 and APH-4 modulated JunB- and c-Jun-dependent transcription differently from HBZ. Deletion mutants indicated that this upregulation of the transactivation potential of Jun factors was mediated through the atypical bZIP domain of APH-3 and $\mathrm{APH}-4$.

\footnotetext{
* Correspondence: larocque.emilie@gmail.com

'Départements des sciences biologiques, Université du Québec à Montréal, Montréal, Canada, H2X 3Y5

Full list of author information is available at the end of the article
}

\section{Conclusion}

We show that HTLV-3 and HTLV-4 express new viral proteins, APH-3 and APH-4, which modulate Jundependent transcription differently from HBZ. These data underscore the importance of our study on APH-3 and $\mathrm{APH}-4$ to help in better understanding the role of HBZ in the development of ATL.

\section{Author details}

${ }^{1}$ Départements des sciences biologiques, Université du Québec à Montréal, Montréal, Canada, H2X 3Y5. ²Départements de microbiologie et immunologie, Université de Montréal, Montréal, Canada, H3T 1J4. ${ }^{3}$ Centre des Études des Agents Pathogènes et Biotechnologies pour la Santé (CPBS), Université Montpellier 1, CNRS/UM1/UM2 UMR 5236, Montpellier, France.

${ }^{4}$ Division of HIV/AIDS Prevention, National Center for HIV, AIDS, Viral Hepatitis, STD, and TB prevention, Centers for Disease Control and Prevention, Atlanta, GA, 30333, USA.

Published: 6 June 2011

doi:10.1186/1742-4690-8-S1-A141

Cite this article as: Larocque et al:: HTLV-3 and HTLV-4 antisense proteins activate JunB-, c-Jun- and JunD-dependent transcription. Retrovirology 2011 8(Suppl 1):A141.

Submit your next manuscript to BioMed Central and take full advantage of:

- Convenient online submission

- Thorough peer review

- No space constraints or color figure charges

- Immediate publication on acceptance

- Inclusion in PubMed, CAS, Scopus and Google Scholar

- Research which is freely available for redistribution

Submit your manuscript at www.biomedcentral.com/submit
( Biomed Central

\section{Ciomed Central}

